\title{
SYMPOSIUM: OCCUPATIONAL HEALTH AND SAFETY
}

\section{Introduction: New Zealand occupational health and safety legislation viewed against the world scene}

\author{
Ian B. Campbell
}

Recent issues of this journal have contained articles dealing with safety and health issues in industrial relations (Benson, 1981; Hamilton and Penney, 1982; Beaumont and Leopold, 1982). These articles reflect an awareness of occupational safety and health issues which has been developing over the last decade; both in New Zealand and overseas. This development prompted the journal to advertise for papers for a symposium on occupational safety and health. The response was very great indeed. Of the papers offered, 6 were selected for publication. These papers provide an interesting mix of case studies, national surveys and international comparisons. The papers are: Paul Duignan - "Occupational health and safety in New Zealand"; Tjord Kjellstrom - "Some crucial issues concerning the safety provided by occupational health standards"; Ross Wilson - "Accident compensation : a union view"; James Chelius - "The American experience with occupational safety and health regulation"; John Leopold and Phil Beaumont - "Health safety and industrial relations: a UK study; and Tom Dwyer - "A new concept of the production of industrial accidents" (based on work done in France).

In view of the wide range of country studies, and the comparative approach adopted in several of the papers, it seemed appropriate to have an introductory article which contrasted the New Zealand scene with developments in other countries. Ian Campbell, teaching fellow in safety management at Massey University, kindly consented to contribute such an article. Prior to his appointment at Massey, Mr Campbell was Director of Safety at the Accident Compensation Commission and, before that, Secretary of the Workers Compensation Board. We are very grateful for Mr Campbell's introduction which he has entitled: "New Zealand occupational health and safety legislation viewed against the world scene".

On 1 August 1978, the Evening Post quoted the then Minister of Labour as saying: "At present, anything up to 6 inspectors arrive on the scene of an accident". Comments such as this have been made from time to time especially with respect to the construction industry, where on one site there could be a question of complying with several acts as well as local body requirements. Such was the background to the appointment by the State Services Commission of Dr Ian K. Walker to look into the criticisms that health and safety matters were the concern of too many different departments administering too many acts and regulations. Dr Walker reported to the Commission in late 1980 and his report is still under consideration.

To the suggestion that the requirements laid upon employers are to be found in too many different statutes could be added another important issue : namely that those statutes are for the most part concerned with many matters additional to that of occupa- 
tional health and safety. If there is validity in the arguments that gave rise to the inquiry, a point few would dispute, then it is all the more to be regretted that only recently there has been passed the Factories and Commercial Premises Act 1981 and the Quarries and Tunnels Act 1982, both of which perpetuate the status quo. Another issue which has clouded the picture in the past is the tendency to consider this solely as an administrative matter, with the government departments concerned being not without self-interest; this could well have been a factor behind the State Services Commission taking the initiative that it did. If that be so, then a quick survey of developments overseas points to the wider aspects involved in this important subject.

Of all the more recent health and safety legislation, probably the best known are the Occupational Safety and Health Act 1970 of the United States and the Health and Safety at Work etc. Act 1974 of Britain. How much less well known would be the recent Canadian legislation; the latest being the Occupational Health and Safety Act 1979 of Quebec; however preceding that act were similarly titled acts of a number of other provinces: Saskatchewan, 1972 and 1977. Alberta, Manitoba and New Brunswick, 1976, Newfoundland and Ontario, 1978. Then in Australia, there are the Industrial Safety, Health and Welfare Acts of 3 states: South Australia, 1972, Tasmania, 1977, and Victoria, 1981. At the time of writing, there is an Occupational Health and Safety Bill before the New South Wales Parliament. Paradoxically, despite the fact that this bill followed on after a commissioner had held hearings on this subject had tabled a report and the matter had been widely debated, the bill has drawn widespread criticism from both management and labour as well as from safety professionals. As would be expected there is, in all this legislation, a great deal of food for thought.

What, in New Zealand as elsewhere, seems to have been given little consideration, however, is the very pertinent question of the effectiveness of such legislation. In this regard, it is perhaps worthwhile recording that in the United States there have been many attempts both to prove and to disprove, whether the 1970 legislation has had any effect on the accident rate, without reaching a conclusion that has found general acceptance. Most agree that it has generated a great deal more interest in occupational health and safety but it can be argued that much more than mere interest is needed.

The United States legislation provides a unique aspect, for the controversy which has plagued it has now turned full circle. Whereas initially, business interests were loud in their clamour against both the Act itself and the manner of its administration, today it is organised labour that is very concerned with the trend of events under the Reagan regime. Their concern, lies not with the concept of the legislation but with what they see as a drastic watering-down in its effectiveness through current administration policies. There are few who would deny that, at the outset, the Occupational Safety and Health Administration (OSHA) made many mistakes but in the years that have followed its formation, many of those errors were rectified. It is, however, in the nature of things that initial impressions, especially if they are adverse, tend to stick. No doubt this is a factor in the degree of support that the administration appears to have received with respect to its roll-back measures against OSHA.

The enforcement agency which is satisfied with the size and calibre of its inspectorate in all probability does not exist. By any standards, however, the size of the OSHA inspectorate was pitifully small when considered against the task that it is expected to perform both in the terms of the legislation and by the nation, even without the recent reduction in numbers. Whatever views one may have about the reasonableness of that reduction, it cannot be denied that it then became all the more essential that those meagre resources be so deployed that the maximum effectiveness is obtained. It makes little sense that an inspector spend his time in an undertaking where compliance with regulations is first class and even more importantly, where the system is excellent and well managed, when there are so many other workplaces crying out for attention. However the announcement by OSHA of the "targeting" system giving an indication of exemption from inspection for many employers on the basis of self-generated statistical data concerning accident rates, was naive to say the least. How much more to be preferred was the system adopted in Britain by the Health and Safety Executive. There, it was also realised that some order of 
priority for inspection had to be developed, but in doing so, the individual employer's accident record was only one of the factors taken into account; the really important feature of their approach is that they do not reveal to employers where they stand in order of priority.

The AFL-CIO's industrial union department, estimates that the "targeting" directive will exempt 75 percent of all manufacturing firms employing some 13 million workers from inspection. It is therefore not without some considerable justification that organised labour is concerned at the tremendous cuts in the OSHA budget. Allied with the reduction in enforcement are other cuts. In most countries it is the threat of prosecution rather than the actual prosecution itself which is important, despite the generally small penalties. However in the United States to-day, the contention of the unions is that this no longer applies as the cutback in inspections has to be viewed against all the other roll-back measures especially in the watering down of standards aimed at the protection of workers.

As an indication of the reduction in OSHA compliance activitiy, an AFL-CIO analysis of such statistics shows declines in monthly figures February to November 1981, compared with January to October 1980 as follows:

- total compliance inspections down 21 percent

- complaint inspections down 32 percent

- follow-up inspections down 72 percent

- $\quad$ serious citations down 33 percent

- wilful citations down 79 percent

- $\quad$ repeat citations down 48 percent

- failure to abate penalties down 78 percent

- worker complaint backlog up 105 percent

AFL-CIO now complain that, since the beginning of 1982 , such data are no longer available.

The so-called "walkaround pay" regulation, which guaranteed that the pay of workers would not be docked for the time spent talking to an inspector or assisting OSHA inspectors was revoked last year.

Again, the contrasting views from Britain are of considerable interest. The Employment Committee of the House of Commons recently heard evidence on the working of the Health and Safety at Work etc. Act 1974, thus commemorating the 10th anniversary of the presentation of the Robens Report, and their summary of the views of the Confederation of British Industry and the Trade Union Congress was:

The CBI in their evidence drew attention to a number of problems which they considered had arisen in the operation of the $A c t$, e.g. the load of work for industry, overlaps between legislation and the responsibilities of departments, inconsistencies in the operations of inspectorates, particularly in the local authority field, and uncertainty over the status and the role of codes of practice and guidance notes. But their general conclusion was that the Commission have succeeded in making the Act work well. In particular they thought the Commission had achieved effective consensus and an increased commitment from both sides of industry to an extensive programme of legislation.

The TUC view is that despite constraints, particularly shortage of manpower resources, the reform of occupational health and safety in the UK which flowed from the Robens Report has been successful. They consider that the Health and Safety Commission has proved a major success in exercising a leading role in the health and safety field, consulting those affected by the proposals for new health and safety legislation and securing consensus about new proposals.

The Committee did further comment:

While recognising that the Commission have achieved consensus on new legislation, the Committee were concerned that this might have been at the expense of reasonable expedition, or progress in controversial areas.

In Britain, whilst it cannot be denied that the inspectorate is also thin on the ground, there are signs that a considerable effort is being mounted to ensure more effectiveness. 
For example, the Health and Safety Executive inspectorate has changed the initial emphasis of its inspection routine. The first task of an inspector now is to endeavour to establish the effectiveness of the management style. The rationale is simply that is is considered that, the better the management system and its control, the more likely are the regulatory requirements to be carried out; as well as the multiplicity of other factors which contribute towards a healthy and safe workplace. Perhaps even more important, the poorer the system and its management, the more likely it is that the inspector should devote time to that establishment. As an indicator of the need for a reassessment of the deployment of the inspectorate, the New Scientist (1983) reports that the Health and Safety Commission have shed more than 500 jobs since 1980 and that more will have to go in order that more highly-paid staff may be recruited from the nuclear industry to look after the nuclear installation's inspectorate work owing to Britain's revived nuclear power programme.

\section{Self-regulation}

Robens publicised this phrase and, ever since the Robens report was issued in 1972, this concept has been much argued, often at cross purposes. The suggestion was early criticised by some writers in Britain, for example Kinnersley (1973) who could not see how employers, who because of their apathy were not complying with the various statutory requirements, could suddenly become very compliant with self-regulation. On the other hand, one could question whether that was really what Robens meant, especially when the report goes on to record that the inspectorate found the threat of prosecution, with its local adverse publicity to be a potent deterrent. And again, there was reference to administrative sanctions as well as criminal proceedings in the most flagrant cases.

A most interesting report is that of the Royal Commission on the Health and Safety of Workers in Mines presented to the Ontario Privincial Government in 1976; generally referred to as the Ham Report after the Comissioner, Dr James Ham. He like Robens was convinced that it was the people in the workplace that, in the long run, would ensure safer and healthier conditions. His report concluded:

The acceptable levels of risks at work and in life-style are being redefined by society. It is essential that this process be marked by a higher measure of openness than has hitherto characterized government and industrial policy. Openness, contributive participation by workers, and thorough accountability can re-establlish the self-regulatory character of the internal responsibility-system at the company level as the key to the control of risks at work in a technologically complex future. The regulatory and auditing functions of the Occupational Health and Safety Authority should be designed to keep the internal system at the company level alert and responsive and to deal bluntly with the true offender.

The Commission believes that the objective of a sound balance between selfregulation and legal compulsion based on the constructive co-operation of all parties cannot be achieved within current government policy and traditional industrial practices. It has formulated its recommendations to promote the change it considers necessary for the future well-being of workers in mines and plants.

It is interesting to record that though the Ham Report was concerned with health and safety in mines, it led to the passing of the Occupational Health and Safety Act 1978 which covers all industry and that the Mines Inspectorate was brought under the Ministry of Labour.

\section{Joint management-labour committees and workers' representatives}

In a great deal of the occupational health and safety legislation passed in recent years, there is provision for compulsory joint management-labour health and safety committees and for the appointment of workers' health and safety representatives. In Britain, despite the time it took following the 1974 Act to get the necessary regulations through, there has 
been no outcry from employers as to the manner in which the new regulations are working out in practice. No doubt, the tremendous effort by the trade union movement in the training of workers' safety representatives may well have paved the way for a more effective introduction of this innovative change. The fact that worker representatives have been the order of the day for many years in Sweden has gone largely unnoticed by most of the legislators in the rest of the world until relatively recently.

With respect to the position in Canada, Clarke (1982) comments:

... full worker participation in health and safety in Canada is of very recent date. It has come about through the legislative process, aided by collective bargaining. Although it was initially greeted with scepticism by the trade union movement.

A proper evaluation of Canada's various joint labour-management health and safety programmes has not yet been conducted. Because the situation varies significantly according to the legislation applicable, it is difficult, if not impossible, to draw conclusions of nation-wide relevance. Nevertheless, Saskatchewan's experience, which is more extensive than that of the other provinces, is at least indicative of the potential impact of worker participation in this area of Canadian life.

If they are given the right to information, the right to participation and the right to refuse dangerous work, workers can influence the work environment significantly. The Saskatchewan experience has shown that joint health and safety committees have so far been much more involved in safety than in health matters. That is not surprising, since occupational health is a relatively new concern in Canada, mainly because little information is available on the causal relationships between certain substances and work processes and health hazards. Occupational health experts, management and workers will require considerably more knowledge before health and safety committees can have any real impact in this increasingly complex area.

These views accord with those expressed in Britain by the Parliamentary Employment Committee.

Thus it is not only the legislation itself which is important, and even its enforcement, but the training and education which both supplements and complements it. An interesting approach is to be seen in a recent development in Ontario. The Industrial Accident Prevention Association (IAPA) put the suggestion to its members that some form of training was needed for the now compulsory health and safety committees; this received a positive response and as a result, with the help of outside consultants, a programme has been developed. The programme entitled "Learning Together" is taken in-house without outside assistance. One member of the committee is sent to attend a 1-day seminar to learn the skills of being a discussion leader and thereafter runs the programme which is organised on a modular basis. The initial exercise requires the committee to convince themselves that they can work together for the common good. Modules are still being developed which will cater to the particular needs of the major industries.

In line with, even if a little more tentative than some of the more positive moves being taken in some of the legislation referred to, is the provision in New Zealand's recently passed Factories and Commercial Premises Act 1981 which enables regulations to be made covering all undertakings or specific classes of undertakings, requiring the establishment of joint health and safety committees and the appointment of workers' safety representatives.

\section{Advisory committees}

The recent Australian legislation provides for the setting up of advisory committees to assist the administering authority. It remains to be seen how effective such committees can be. In Ontario, not only is there such a committee, but it is provided with a secretariat and even more important some research officers. Its functions are: (1) To make recommendations to the Minister of Labour relating to programs of the Ministry in occupational health and occupational safety: and (2) To advise the minister on matters relating to 
occupational health and occupational safety which may be brought to its attention or referred to it.

To achieve this the Council has set the following objectives:

Primary Objective

To advise the Minister of Labour on all matters relative to occupational health and safety in Ontario.

Second Objectives

(1) To ensure as far as possible that the policies and programs in occupational health and safety effectively minimize the risks to health and safety in all workplaces in Ontario.

(2) To ensure as far as possible that knowledge about occupational health and safety is available to management, labour and the public and that it is understood by them.

(3) To assist in promoting and establishing mechanisms involving management and labour to solve problems in occupational health and safety.

(4) To ensure as far as possible that there is appropriate manpower training and development for the occupational health and safety field.

(5) To review periodically the effectiveness of policies and programs implemented to achieve secondary objectives 1 to 4 .

There are also lengthy terms of reference all of which go to ensure that this is an effective committee making a positive contribution, a factor which can be judged from the Committee's quite extensive annual report.

In New Zealand, for many years there has been an advisory committee with respect to the Construction Act 1959. Though set up by Government, it has no formal basis and does not meet very often. But those concerned with it consider that it does perform a useful function. As a further indication of the piecemeal basis on which we approach the occupational health and safety problem in New Zealand, there has been recently set up an occupational health advisory committee. If we were to follow the accepted practice in most western countries, a single unified statute would ensure that we would be rid of this fragmented approach.

The cost of occupational health and safety measures

In the early days of Workers' compensation it was accepted that by imposing the cost of compensation upon employers there was a financial incentive for them to adopt preventive measures. Such a view presupposes that employers are aware of the measures that they should adopt and have the means to implement them. This, as anyone who has been involved in endeavours to persuade employers to adopt preventive measures will testify, is far from reality. For many years the United States have used a number of plans whereby the Workers' Compensation premium of the employer may be varied in accordance with the individual accident record. Even in New Zealand, section 95 of the Workers' Compensation Act 1956 provided for the imposition by the Workers' Compensation Board of penalties on the premiums of employers in certain cases. More recently, the Accident Compensation Corporation (ACC) has granted rebates to employers with significantly better than average accident records, though it has so far refrained from imposing penalties but is empowered so to do. Unfortunately this provision in the Accident Compensation Act 1982 makes the corporation's task much more onerous.

What is far less clear, is the effect of these measures on the health and safety scene. This has been discussed at length elsewhere (Campbell, 1980). What can be argued, however, is the justification or otherwise of comparing the imposition of the costs of health and safety measures upon employers as against the benefits to the workers. Here, to some extent, we must enter the realm of speculation which is not assisted by the imprecision of some of the language used in the statutes apart from any problem of quantification. The United States Supreme Court has recently given a judgement where the question at issue was whether the 
requirement of "feasibility" in section 6 (b) (5) of the Act mandated, prohibited or permitted consideration by OSHA of cost-benefit analyses prior to setting standards for permissible levels of toxic substances in places of employment. (American Textile Manufacturers Institute Inc v. Donovan (1981) generally referred to as the "cotton dust" case.) The majority decision was that cost-benefit analyses were neither required nor permitted by the Act. An exception would be if the costs were such that would prevent the goal of the legislation from being achieved. In other words, the requirement resulted in the destruction of the whole industry.

It is no wonder that one Canadian study comments:

There is a need for more formal consultative approaches in the setting of standards and guidelines in Ontario without adopting the excesses of "due processitis" which plague the American regulatory scene. Both business and labour groups are leery of adopting the American approach, particularly its inevitable reliance on the courts.

The same study goes on to discuss the role of cost-benefit analysis:

The burden of proof argument always begs the question, "burden of proof of what?" Once the human health effects are identified, standard-setting invariably and unavoidably involves questions of "proof" involving politics and economics. One is no longer judging just the existance of health effects but rather the acceptability of risks and health effects. Such judgements cannot help but involve both the economic and political calculus of costs and benefits. Such a "calculus" can be primarily hidden, as it has tended to be, and based on private "behind-the-scene" political and economic bargaining among the interests at stake. All parties in the health and safety regulatory process have practiced such private political costbenefit trade offs. Businesses do it in the choice of capital equipment and the speed with which they install better health and safety technologies. Labour unions have done it by trading off (implicitly or explicitly) health and wage benefits, not to mention jobs and job security. Regulators do it by varying the speed of the regulatory response and the tenacity of their enforcement.

The question therefore is not whether one should have or will have costbenefit calculus in the standard-setting process but whether it will be assessed privately pr publicly. While we have no particular desire to create more employment for economists, we do think that, on balance, formal and more open politi$\mathrm{cal}$ and economic cost-benefit analysis is referable to a system based almost wholly on private cost-benefit bargaining. We are very conscious of the abuses of formal cost-benefit analysis but would still regard the need for such published assessments as a useful reform provided that they are accompanied by other institutional changes needed for the initial technical identification of hazards noted above. We therefore regard experiments such as the federal SEIA (socioeconomic impact assessment) process to be well worth trying in a regular way in the Ontario government. They should be a formal public part of the consultative approach proposed above.

The SEIA process applies when the regulations proposed are likely to impose private sector costs in excess of $\$ 10$ million.

Ashford (1976) quotes a study by a firm of consultants with respect to proposed noise levels which estimated the cost of complying with a $85 \mathrm{dBA}$ level as over $\$ 31$ billion for 19 major industries as against $\$ 14.4$ billion for a $90 \mathrm{dBA}$ level. In such studies most of the data and information often lies with those being regulated. Again, many of the costs and benefits defy quantification while the latency of the effect on humans of many hazardous substances and the long-term nature of many remedies serve further to complicate this difficult issue. Nevertheless it is logical that the maximum possible effort should be made to establish both cost and benefit, if only to assess priorities for action. 


\section{The moral issue}

Costs and benefits alone are, however not the only issue to be considered. In a thoughtprovoking paper entitled "Human Rights and the Prevention of Cancer" Gerwith (1980) makes a number of pertinent comments. He maintains that where it is known that substances in use are causally related to cancer, then exposure to those substances must be prohibited or at least carefully regulated and additionally that every effort must be made to get the relevant knowledge and publicise it. Thus where manufacturers, employers and sellers of such substances do nothing to stop or curtail their use or marketing, they can be morally and causally held responsible for any cancers which may thus be inflicted. Gerwith concludes:

So far as the moral responsibility of agents is concerned, the Right to the NonInfliction of Cancer is an absolute human right, and it requires the most determined efforts both to ascertain when such infliction is likely to occur and to take all possible steps to prevent it, and thereby to make its respondents fulfill their correlative duties.

Yet there is evidence that, at times, such information has been deliberately witheld. Benson (1981) in his examination of the VIC RAIL asbestos dispute demonstrates how such issues cannot be left to management or the government and illustrates the need for workers and union officials to be involved in assessing the dangers present.

\section{Regulation of the the work environment in New Zealand}

\section{Section 36 of the Factories and Commercial Premises Act 1981 states:}

Removal of steam, fumes and dust - (1) The occupier of an undertaking in which any process is carried on that gives off -

(a) Any steam, fume, dust or other inpurity, of such a character and to such an extent as to be likely to be injurious or offensive to any worker employed in that undertaking; or

(b) Any substantial quantity of dust of any kind shall take all practicable steps to ensure that the workers are protected against inhalation of that steam, fume, dust, or impurity, and that it is prevented from accumulating in any workroom.

Relatively few regulations have been promulgated with respect to specific substances. That relating to asbestos is the most comprehensive. Others relate to abrasive blasting, electro-plating, lead, noxious substances and spray coating. In the administration of these regulations, considerable reliance is placed by the Department of Labour on the expertise of the Department of Health. That department regularly issues a guide entitled "Threshold Limit Values " (TLVs). The TLVs set out in that guide have been based on a list adopted by a meeting of the American Conference of Government Industrial Hygienists (ACGIH) in 1980. An appendix to the booklet sets out the TLVs for some substances where the New Zealand standard differs from that adopted by the ACGIH. In the introduction, the following comments appear under the heading of "Policy":

The policy of the Department of Health on Threshold Limit Values is as follows:

(1) The Treshold Limit Values adopted are not specifically recognised by any legislation in New Zealand, but they are used as a standard by which to assess whether or not a factory or business premises complies with the requirements of section 36 of the Factories and Commercial Premises Act 1981.

(2) The Treshold Limit Values should not be regarded as marking a boundary between safety and danger. Because of wide variation in personal susceptibility some workers may experience discomfort at levels well below the Threshold Limit Values. Therefore the level of any airborne contaminent should (3) be reduced to the lowest practicable below the Threshold Limit Value. 
(4) The use of protective equipment by the worker in order to achieve a level below the Threshold Limit Value should be regarded as the last resort, only to be adopted after all reasonable engineering precautions have been implemented to reduce the exposure level.

Thus we see further evidence of the difficulties faced by the regulators apart from the fact that there is no guarantee that the keeping of the level of the contaminant below the TLV will ensure complete ummunity.

\section{Conclusion}

There is ample evidence from this brief introduction that there is much for us to learn in New Zealand from the manner in which many countries with whom we have close ties are developing their strategies, both regulatory and otherwise. The Canadian study to which reference was made is but one of a number of background studies prepared for the Royal Commission on Matters of Health and Safety Arising from the Use of Asbestos in Ontario. It is a thorough document and is illustrative of the wealth of material available to assist us in New Zealand. For the most part, it, like other similar material, is very relevant to our scene, a factor that is not always fully appreciated; some will persist in seeing our country as being as more than a little unique and often fail to appreciate that basically many of our problems are the same as those of more highly industrialised countries. We too have our ambivilance of which Calabresi and Bobbitt (1977) speak:

Consider the different attitude we all share toward the failure of Congress to pass truly effective safety legislation, as against the attitude we would have were it unwilling to appropriate funds for the rescue of a trapped hostage. Lives may be discarded in both cases, but the choice is less exposed in the first case, and therefore less destructive of some basic values involved.

Much yet remains to be done if we are to release more of the hostages trapped by the unhealthy and unsafe aspects of our workplaces and the activities being carried on therein. One could seriously question whether we have the ability to recognise all of those aspects, especially those that affect health. All the evidence points to the fact that what are currently being recognised as work-related illnesses are but the tip of a very major problem. Is it too much to suggest that our needs lie rather in a substantial upsurge in our occupational health and safety education, and education that must embrace not only the professionals but equally management and workers, trade union officials and the inspectorate? The clear message from the United States, Canada and other countries to-day is the need for greater knowledge and awareness in the workplace espacially with the ever growing hazards to the health of those employed therein.

\section{References}

Advisory Council on Occupational Health and Occupational Safety (1982) Fourth Annual Report. Toronto.

Ashford, N. (1976) Crisis in the workplace : occupational disease and injury Cambridge, Mass. MIT Press.

Benson, J. (1981) Union involvement in health issues : The. VIC RAIL asbestos dispute New Zealand journal of industrial relations 6 (2) : 57-65.

Calabrisi, G. and Bobbit, P. (1977) Tragic choices New York, Norton.

Campbell, I.B. (1980a) Accident statistics and significance : their practical application in New Zealand Palmerston North, Faculty of Business, Massey University.

Campbell, I.B. (1980b) Accident prevention activity : its need and its measurement Control $6(4): 131-146$. 
Campbell, I.B. (1982) Safety legislation and the workplace : the international scene : comparisons and conclusions Palmerston North, Faculty of Business, Massey University.

Campbell, I.B. (1983) Safety education and enforcement : what can we learn from Ontario? Industrial law bulletin (1) : 9-11.

Clarke, R.D. (1982) Worker participation in health and safety in Canada International labour review 121 (2) : 199-205.

Doern, G.B. et al (1982) Living with contradictions : health and safety regulation and implementation in Ontario Ottawa, School of Public Administration, Carleton University.

Gerwith, A. (1980) Human rights and the prevention of cancer American philosophical quarterly $17: 112-125$.

Health and Safety Commission (1983) New Scientist 97 (343) : 289.

Kinnersley, P. (1973) The hazards of work : how to fight them London, Pluto Press.

Royal Commission on the Health and Safety of Workers in Mines Report (1976) Toronto, Ministry of the Attorney-General.

The role of health and safety committees (Learning together) (1982) Toronto IAPA.

New Zealand Department of Health (1982) Threshold Limit Values Wellington.

Walker, I.K. (1981) Occupational safety : an inquiry into the co-ordination of legislation on industrial safety, health and welfare Wellington, State Services Committee.

Williams, T.G. (1981) Report of the Commission of Inquiry into Occupational Health and Safety Sydney, Minister of Industrial Relations.

Workshop 2, (1982) Washington, IUD, AFL-CIO.

Case

American Textile Manufactures Institute Inc. et al. v. Donovan and National Cotton Council of America v. Donovan, US Supreme Court, June 17, 1981. 